\title{
Effects of EFL Learners' L2 Writing Self-efficacy on Engagement with Written Corrective Feedback
}

\author{
Jui-Jung Tsao ${ }^{1}$ (D)
}

Accepted: 10 May 2021 / Published online: 20 May 2021

(C) De La Salle University 2021

\begin{abstract}
Research has indicated the integral role of selfefficacy in boosting learner engagement. Yet, little research on this issue has been conducted in the field of L2 writing. The purpose of this quantitative study is to explore how EFL learners' L2 writing self-efficacy affects the level of their engagement with teacher and peer written corrective feedback (WCF). A sample comprising 227 Taiwanese senior high school students completed two questionnaires: the learner engagement with written corrective feedback scale and the L2 learners' writing self-efficacy scale. The results showed that the participants self-reported a low-tomoderate level of L2 writing self-efficacy. In addition, when all three subtypes (i.e., ideation, conventions, and self-regulation) of L2 writing self-efficacy were taken into account, self-efficacy for writing self-regulation was the only variable with predictive power for learner engagement with teacher and peer written corrective feedback. The findings further our understanding of EFL learners' L2 writing self-efficacy and of the under-researched topic of the relationship between L2 writing self-efficacy and learner engagement with written corrective feedback.
\end{abstract}

Keywords Learner engagement - Writing self-efficacy · Written corrective feedback

Supplementary Information The online version contains supplementary material available at https://doi.org/10.1007/s40299-021-00591-9.

Jui-Jung Tsao

a71747174@gmail.com

1 Department of Applied English, Ming Chuan University, Taoyuan, Taiwan

\section{Introduction}

Writing has been regarded as an incredibly difficult skill for language learners to fully master, particularly in English as a foreign language contexts where learners may encounter difficulties relating to aspects of cognition such as rhetorical competence, linguistic knowledge, and thinking strategies, and resulting from an inability to cope with the negative effects of individual affective factors (e.g., having low self-efficacy) during the complex and rigorous writing process (Kavanoz \& Yüksel, 2016; Simin \& Tavangar, 2009; Berdanier \& Lenart, 2020). Many teachers who have tried to help learners improve their writing skills by offering them written corrective feedback (WCF) may have been motivated by the belief that feedback can enhance learners' writing skills if delivered effectively. However, due to the difficulty of becoming a competent writer in an L2, language learners tend to disengage from learning tasks (Lynch et al., 2019) by, for example, responding ineffectively or even failing to respond to teacher and/or peer feedback. Therefore, whether WCF is received attentively, an issue that tends to be ignored (Zhang \& Hyland, 2018), merits greater attention because feedback without engagement is completely unproductive (Price et al., 2011). In addition, as Shaughnessy (1977) argued, writing is a process that requires confidence. Successful writing processes, therefore, rely not only on cognitive knowledge but also on positive selfefficacy in relation to employing knowledge and engaging in self-regulating learning behavior (Teng et al., 2018). Many EFL learners have reported having little confidence in their writing ability (Zhang, 2018), which may negatively affect their writing performance (Woodrow, 2011). Therefore, it is important to support EFL learners in becoming L2 writers with high self-efficacy. Multiple 
studies have argued that self-efficacy is a key variable that influences engagement (Linnenbrink \& Pintrich, 2003; Schunk \& Mullen, 2012; Sharma \& Nasa, 2014). Nonetheless, because of the stress and uncertainty caused by the COVID-19 pandemic and lockdown, students perceive themselves as having less self-efficacy in their academic studies, which may in turn have a negative effect on their learning (Alemany-Arrebola et al., 2020). The distinctive rise in online learning (which is markedly different from bricks-and-mortar education) during lockdown has triggered a question: How does learners' self-efficacy influence their engagement in learning activities (i.e., engaging with teacher and peer WCF in this particular study) when they are at home practicing social isolation? Therefore, the purpose of the current study was to explore how EFL learners' L2 writing self-efficacy as a multifaceted construct affects their engagement with teacher WCF and peer WCF, respectively.

\section{Literature Review}

\section{Learner Engagement with WCF in L2 Writing}

The level of learner engagement with WCF can be defined as learners' active involvement in decision-making during the writing process (Myhill \& Jones, 2007), that is, the "state of being involved, occupied, retained and intrinsically interested" (Kim et al., 2013, p. 363) in deeply processing WCF. Although learner engagement remains largely underexplored in L2 writing (Zhang \& Hyland, 2018), some research studies have attempted to shed some light on the multifaceted but interdependent nature of student engagement with WCF. For example, Ellis (2010) examined the construct in relation to three categories: cognitive (i.e., learners' conscious engagement with feedback), behavioral (i.e., learners' uptake and revisions prompted by feedback), and affective (i.e., learners' attitudinal responses to feedback). A critical addition to the categories is social engagement (e.g., how interactive with others and how supportive of others the learner is; Svalberg, 2012). The relationships between WCF, learner engagement, and writing achievement have also been identified in previous empirical studies. For example, peer feedback (Yu et al., 2020) and indirect feedback (Zhang, 2017) may trigger more student engagement. The quality of notice (Qi \& Lapkin, 2001) and the extensiveness of learner engagement may contribute to writing outcomes. Furthermore, Tsao et al. (2017) found that learners' intrinsic motivation and anxiety about writing tests and making mistakes could predict their self-evaluative judgments of teacher and peer WCF. Student preferences for teacher feedback either on local or on global errors were also discovered in previous studies (Hedgcock \& Lefkowitz, 1994; Horbacauskiene \& Kasperaviciene, 2015).

\section{L2 Writing Self-efficacy}

Self-efficacy refers to people's judgment of their ability to organize and execute the course of action required to attain designated goals or types of performance (Bandura, 1995). The literature on writing development includes studies where researchers have developed and validated scales for measuring learners' self-efficacy beliefs in writing skills. For example, in terms of L1 writing, Bruning et al. (2013) developed the Self-efficacy for Writing Scale, which examined students' self-efficacy for writing ideation, writing conventions, and writing self-regulation. While scrutinizing L2 learners' writing self-efficacy, Teng et al. (2018) designed the Second Language Writing Self-efficacy Scale. The positive relationship between writing selfefficacy and writing performance has been confirmed in some empirical research (Bruning et al., 2013; Daniels et al., 2019; Pajares \& Valiante, 1999; Teng et al., 2018; Zimmerman \& Bandura, 1994; Zumbrunn et al., 2019). Other research focuses on corroborating the positive relationship between self-efficacy and learner engagement (Caraway et al., 2003; Lindsey, 2017; Linnenbrink \& Pintrich, 2003; Price et al., 2011; Quweneel et al., 2013; Putarek \& Pavlin-Bernardić, 2020).

Previous studies, as discussed, have brought to attention the importance of understanding and enhancing learner engagement with WCF and writing self-efficacy and of exploring the relationship between the two variables. As Bruning et al. (2013) argued, writing is a demanding domain in which motivational conditions are less than ideal. Therefore, to help L2 learners improve their writing skills, it is critical to understand and find ways to help them develop writing self-efficacy by considering both linguistic and self-regulation skills. Self-efficacy is a major determinant of the level of learner engagement (Papa, 2015; Walker et al., 2006), but the relationship between the two variables has yet to attract much interest in the field of L2 writing (Kirmizi \& Kirmizi, 2015). In particular, how learners' L2 writing self-efficacy promotes the level of their engagement with the WCF provided by teachers and peers still remains underexplored. Furthermore, given the fact that the COVID-19 pandemic and its accompanying lockdown have significantly influenced students' academic studies, self-regulated learning has proved to be the main learning method that can improve student learning (Cai et al., 2020). However, home confinement and its accompanying stress and uncertainty may render students less self-confident in their academic studies (Alemany-Arrebola et al, 2020). Moreover, the writing process, as we all know, 
can be tedious, difficult, and frustrating (Wright \& Pade, 2020). Students need to be self-confident enough to successfully manage, monitor, and evaluate the learning process because "self-regulatory skills are needed not only to generate productive ideas and writing strategies but also to manage the anxieties and emotions that can accompany writing" (Bruning et al., 2013, p. 29). This statement corresponds to Usher and Pajares' (2008) finding that selfefficacy for self-regulated learning positively correlates with achievement in writing. Such being the case, it is crucial for us to help students develop their self-efficacy and, further, to scrutinize whether the three types of L2 writing self-efficacy (i.e., writing ideation, writing conventions, and writing self-regulation in this study), especially self-efficacy for writing self-regulation, can enhance student engagement with WCF to improve their writing competence. Therefore, the current study focuses on the predictive power of writing self-efficacy pertaining to selfregulation skills and to linguistic skills (including writing ideation and writing conventions) for L2 learners' engagement with teacher WCF (ETWCF) and engagement with peer WCF (EPWCF).

With the goal of addressing the gaps mentioned above, two research questions were considered as follows:

(1) What is the status quo of high school students' L2 writing self-efficacy and WCF engagement?

(2) What is the relationship between high school students' L2 writing self-efficacy and their engagement with either teacher WCF or peer WCF?

\section{Methods}

\section{Research Background}

Taiwanese 12th graders were chosen to be the current research participants. In their preparation for university entrance examinations, they had been required to study English as a foreign language for at least 9 years since Grade 3 and had learned some writing techniques such as how to brainstorm before writing or how to compose a paragraph. This means that they had a certain level of writing experience. However, according to some research (Kaoa \& Reynoldsb, 2017), senior high school students in Taiwan are generally poor English writers. In addition, on average, the participants rated their English writing ability as somewhere between "poor" and "just ok" ( $M=2.45$, $\mathrm{SD}=0.91$; on a 6 -point Likert scale) based on the selfreport questionnaire, indicating that all the participants had a relatively low level of confidence in their English writing competence. Therefore, to find ways to help them improve their English writing skills, there is a dire need to explore the level of self-efficacy of this group of students in the English learning process.

\section{Participants}

A convenience sample of 187 Taiwanese 12th graders were recruited in the pilot study. The valid return rate was $91 \%$. Based on the data collected from the pilot study, the proper questionnaire items selected and determined (through item analysis and exploratory factor analysis) for the main study are illustrated below (also shown in the Online Appendices). In the main study, the sample (chosen by convenience sampling) was larger, comprising 227 Taiwanese EFL 12th graders from three senior high schools in northern Taiwan. The valid return rate was 93\%. The average age of the participants in the main study was roughly 18 years old.

\section{Instrumentation}

Self-reported questionnaires were utilized in the present study due to their advantages such as the collection of a considerable amount of quantitative data that can be ensured, and, hence, generalization of the findings (Demetriou et al., 2015). Self-reported questionnaires were also employed for some practical reasons. For example, the current research participants were busy preparing for college entrance examinations and had no time for face-toface interviews.

To develop and validate the scales used in the main study, IBM SPSS Version 20 was used in the pilot study to analyze both reliability and validity. The questionnaires comprised the Learner Engagement with Written Corrective Feedback scale (Two subscales: ETWCF and EPWCF), and the L2 Learners' Writing Self-efficacy Scale (LWSE). A 6-point Likert scale ( $1=$ strongly disagree; 2 = disagree $; \quad 3$ = somewhat disagree $; 4=$ somewhat agree; 5 = agree; 6 = strongly agree), which forces a choice and tends to have a higher trend of discrimination and reliability (Chomeya, 2010), was used to elicit participants' responses to the survey statements.

\section{The Learner Engagement with Written Corrective Feedback Scale}

The 10 items were adapted from Tsao et al. (2017) to assess learners' engagement with teacher and peer WCF due to its focus on five major types of errors: (1) technical details (i.e., contractions, capitalization, and punctuation), (2) grammatical rules, (3) vocabulary/collocations, (4) content, and (5) organizational structure. The first three items in each scale were related to local errors (i.e., technical details, grammar, and vocabulary/collocations), and 
the other two were related to global errors (i.e., content, and organizational structure). All 10 items' corrected itemtotal correlations were above .72 and were, therefore, retained for further analysis. Exploratory factor analysis was performed, and the results indicated two factors that accounted for $84.67 \%$ of the variance $(\mathrm{KMO}=.88$; $\left.\chi^{2}=2236.54 ; d f=45, p<.001\right)$. The first factor was learner engagement with peer written corrective feedback (EPWCF; 5 items), and the second was learner engagement with teacher written corrective feedback (ETWCF; 5 items).

\section{The L2 Learners' Writing Self-efficacy Scale (LWSE)}

The LWSE scale was adapted from two previous studies (Bruning et al., 2013; Teng et al., 2018). The subconstruct performance self-efficacy from Teng et al.'s scale was not included in the current study's self-efficacy scale because it basically examines "learners' confidence in their task-related performance in classroom environments" (p. 921), which is not directly related to the home-learning environment. After performing an item analysis (with the corrected item-scale correlations ranging from .62 to .77), all 12 items in the LWSE scale adapted from two previous studies (Bruning et al., 2013; Teng et al., 2018) were retained for exploratory factor analysis. Item 7 in the subscale of self-efficacy for writing conventions was deleted because it loaded on the factor of self-efficacy for writing ideation. The subsequent factor analysis identifed a three-factor solution that accounted for $77.16 \%$ of the variance $\left(\mathrm{KMO}=.90 ; \chi^{2}=1723.54 ; d f=55, p<.001\right)$. The first factor was Self-efficacy for Writing Self-regulation (4 items), the second was Self-efficacy for Writing Conventions (4 items), and the third, Self-efficacy for Writing Ideation (3 items). Self-efficacy for writing ideation is defined as writers' beliefs about their abilities to generate ideas, and self-efficacy for writing conventions is defined as writers' beliefs about their abilities to express those ideas using writing's language-related tools. Self-efficacy for writing self-regulation refers to writers' beliefs about their abilities to manage, monitor, and evaluate writing activities (Bruning et al., 2013).

Furthermore, each subscale's reliability and validity were tested and verified as shown in Table 1. With respect to the normality of the data ( 227 valid questionnaires in the main study), as shown in Tables 2 and 3, all skewness values and kurtosis values in the scales were acceptable for inferential statistic tests (George \& Mallery, 2001; Kline, 1998).

\section{Data Collection and Analysis}

A two-stage research design was executed: a pilot and a main study. Clear instructions regarding how to fill in the questionnaire were provided. With respect to ethical considerations, all the participants were informed of the purpose and process of the study and were also assured of the integrity and confidentiality of the data prior to signing the consent form.

In the main study, the linearity assumption was determined with scatter plots. Therefore, hierarchical regression analyses were performed to determine whether independent variables (i.e., the three variables in the LWSE: selfefficacy for writing ideation, conventions, and self-regulation) could serve as a predictor for the two dependent variables (i.e., ETWCF and EPWCF) separately by showing a significant improvement in $\mathrm{R}^{2}$ (the proportion of explained variance in dependent variables by the model). Specifically, generating ideas as we know is the first step of the writing process; therefore, it is crucial to know whether the level of participants' confidence in generating ideas could predict their engagement with the two types of WCF. Accordingly, in step 1 , only one control variable-selfefficacy for writing ideation-was entered into the first regression model. In step 2, the self-efficacy for writing conventions variable was added to create Model 2 to identify the predictive power of the two independent variables (i.e., self-efficacy for writing ideation and for writing conventions). Self-efficacy for writing self-regulation was then added to Model 3 to test its importance in the writing process, in accordance with Bruning et al.'s (2013) claim.

\section{Results}

Q1: What is the status quo of high school students'

L2 writing self-efficacy and WCF engagement?

As Table 3 shows, in general, all the participants rated the strength of their belief in their English writing ability as low-to-medium $(M=3.18, \mathrm{SD}=.92)$. Specifically, they appraised their self-efficacy for ideation $(M=2.99, \mathrm{SD}=$ $1.08)$, conventions $(M=3.28, \mathrm{SD}=1.03)$, and self-regulation $(M=3.23, \mathrm{SD}=1.08)$ as low-to-medium. According to the results of paired samples $t$ tests in Table 4, no difference was found between participants' self-efficacy for writing conventions and for writing self-regulation. Thus, we argue that their self-efficacy for the two aspects is at the same level. However, self-efficacy for writing ideation ranked the lowest. In terms of individual items in the L2 writing self-efficacy scale, as illustrated in Table 3, the lowest score in the factor of self-efficacy for writing 
Table 1 Descriptive analysis of all participants' engagement with WCF on individual local and global errors

\begin{tabular}{|c|c|c|c|c|c|c|}
\hline & \multirow[t]{2}{*}{$M$} & \multirow[t]{2}{*}{$\mathrm{SD}$} & \multicolumn{2}{|c|}{ Skewness } & \multicolumn{2}{|l|}{ Kurtosis } \\
\hline & & & Statistic & SE & Statistic & SE \\
\hline \multicolumn{7}{|l|}{ ETWCF } \\
\hline & 3.74 & 1.11 & -.51 & .16 & .27 & .32 \\
\hline Item 1 & 3.64 & 1.21 & -.32 & .16 & -.29 & .32 \\
\hline Item 2 & 3.72 & 1.21 & -.54 & .16 & -.14 & .32 \\
\hline Item 3 & 3.78 & 1.19 & -.54 & .16 & .11 & .32 \\
\hline Item 4 & 3.79 & 1.19 & -.47 & .16 & .06 & .32 \\
\hline Item 5 & 3.75 & 1.20 & -.48 & .16 & .01 & .32 \\
\hline \multicolumn{7}{|l|}{ EPWCF } \\
\hline & 3.60 & 1.10 & -.49 & .16 & .03 & .32 \\
\hline Item 1 & 3.52 & 1.18 & -.28 & .16 & -.24 & .32 \\
\hline Item 2 & 3.63 & 1.18 & -.38 & .16 & -.11 & .32 \\
\hline Item 3 & 3.60 & 1.18 & -.38 & .16 & -.16 & .32 \\
\hline Item 4 & 3.64 & 1.17 & -.41 & .16 & -.13 & .32 \\
\hline Item 5 & 3.62 & 1.16 & -.38 & .16 & -.07 & .32 \\
\hline
\end{tabular}

ETWCF learner engagement with teacher written corrective feedback, $E P W C F$ learner engagement with peer written corrective feedback

Table 2 Descriptive analysis of all participants' L2 writing self-efficacy

\begin{tabular}{|c|c|c|c|c|c|c|}
\hline & \multirow[t]{2}{*}{$M$} & \multirow[t]{2}{*}{ SD } & \multicolumn{2}{|c|}{ Skewness } & \multicolumn{2}{|l|}{ Kurtosis } \\
\hline & & & Statistic & SE & Statistic & SE \\
\hline Whole scale & 3.18 & .92 & -.43 & .16 & -.16 & .32 \\
\hline \multicolumn{7}{|l|}{ Ideation } \\
\hline Subscale & 2.99 & 1.08 & -.08 & .16 & -.27 & .32 \\
\hline Item 1 & 3.06 & 1.24 & .07 & .16 & -.38 & .32 \\
\hline Item 2 & 2.83 & 1.18 & .23 & .16 & -.28 & .32 \\
\hline Item 3 & 3.07 & 1.21 & -.05 & .16 & -.64 & .32 \\
\hline \multicolumn{7}{|l|}{ Cons } \\
\hline Subscale & 3.28 & 1.03 & -.31 & .16 & -.27 & .32 \\
\hline Item 1 & 3.56 & 1.22 & -.31 & .16 & -.41 & .32 \\
\hline Item 2 & 3.37 & 1.14 & -.21 & .16 & -.26 & .32 \\
\hline Item 3 & 2.99 & 1.20 & .20 & .16 & -.17 & .32 \\
\hline Item 4 & 3.19 & 1.19 & -.18 & .16 & -.53 & .32 \\
\hline \multicolumn{7}{|l|}{ SR } \\
\hline Subscale & 3.23 & 1.08 & -.30 & .16 & -.09 & .32 \\
\hline Item 1 & 2.97 & 1.22 & -.01 & .16 & -.59 & .32 \\
\hline Item2 & 3.23 & 1.26 & -.01 & .16 & -.35 & .32 \\
\hline Item 3 & 3.07 & 1.24 & -.08 & .16 & -.49 & .32 \\
\hline Item 4 & 3.65 & 1.28 & -.45 & .16 & -.13 & .32 \\
\hline
\end{tabular}

Cons conventions, SR self-regulation

ideation was for Item 2: When writing in English, I can think of many words to express myself $(M=2.83, \mathrm{SD}=$ 1.18). Taken together, these two scores indicate that the participants either did not have an extensive vocabulary to draw on to express themselves and/or could not bring the vocabulary to mind. In the subscale of self-efficacy for writing conventions, the highest score was for Item 1:
When writing in English, I can write complete sentences $(M=3.56, \mathrm{SD}=1.22)$. Yet, the participants still lacked confidence in using grammar: Item 3: When writing in English, I can write grammatically correct sentences $(M=2.99, \mathrm{SD}=1.20)$. These results suggest that although the participants were able to write full sentences, they were not confident in the grammatical correctness of their 
Table 3 The composite reliability and average variance explained of the scale

\begin{tabular}{|c|c|c|c|c|c|}
\hline Constructs & Items & Standardized regression weights & $\alpha$ & $\mathrm{CR}$ & AVE \\
\hline \multirow[t]{3}{*}{ Ideation } & Item 1 & .86 & .87 & .85 & .64 \\
\hline & Item 2 & .76 & & & \\
\hline & Item 3 & .80 & & & \\
\hline \multirow[t]{4}{*}{ Cons } & Item 1 & .82 & .89 & .89 & .67 \\
\hline & Item 2 & .83 & & & \\
\hline & Item 3 & .81 & & & \\
\hline & Item 4 & .83 & & & \\
\hline \multirow[t]{4}{*}{ SR } & Item 1 & .76 & .89 & .89 & .67 \\
\hline & Item 2 & .89 & & & \\
\hline & Item 3 & .87 & & & \\
\hline & Item 4 & .75 & & & \\
\hline \multirow[t]{5}{*}{ ETWCF } & ETWCF 1 & .89 & .96 & .95 & .80 \\
\hline & ETWCF 2 & .86 & & & \\
\hline & ETWCF 3 & .96 & & & \\
\hline & ETWCF 4 & .91 & & & \\
\hline & ETWCF 5 & .86 & & & \\
\hline \multirow[t]{5}{*}{ EPWCF } & EPWCF 1 & .88 & .96 & .96 & .83 \\
\hline & EPWCF 2 & .94 & & & \\
\hline & EPWCF 3 & .85 & & & \\
\hline & EPWCF 4 & .92 & & & \\
\hline & EPWCF 5 & .95 & & & \\
\hline
\end{tabular}

Cons conventions, $S R$ self-regulation, $E T W C F$ learner engagement with teacher written corrective feedback, $E P W C F$ learner engagement with peer written corrective feedback, $\alpha$ Cronbach's alpha, $C R$ composite reliability, $A V E$ average variance extracted

Table 4 The results of paired samples $t$ tests for L2 writing self-efficacy

\begin{tabular}{llll}
\hline Variables & $M$ & SD & $t$ \\
\hline Pair 1 & & & \\
Cons & 3.28 & 1.03 & .72 n.s. \\
SR & 3.23 & & \\
Pair 2 & & 1.08 & $3.66^{* * *}$ \\
SR & 3.23 & 1.08 & \\
Ide & 2.99 & 1.03 & $5.26^{* * *}$ \\
Pair 3 & & 1.08 & \\
Cons & 3.28 &
\end{tabular}

Cons conventions, $S R$ self-regulation, Ide ideation, n.s. non-significant

$* * * p<.001$

sentences. With regard to self-efficacy for writing selfregulation, the participants reported that they were relatively unlikely to start working on an assignment immediately: Item 1: After given a writing assignment by the teacher, I can start working on it quickly $(M=2.97$, $\mathrm{SD}=1.22$ ). Their ability to overcome difficulties and persevere in their writing was moderate: Item 4: I can keep writing even when encountering difficulties $(M=3.65$,
$\mathrm{SD}=1.28)$. However, this item received the highest score in this subscale.

RQ2: What is the relationship between high school students' L2 writing self-efficacy and their engagement with either teacher WCF or peer WCF?

The relationships between L2 writing self-efficacy and the participants' engagement with WCF were examined using hierarchical multiple regression. As shown in Table $5, R^{2}$ 
Table 5 Results of the hierarchical multiple regression: predicting ETWCF from L2 writing self-efficacy

\begin{tabular}{|c|c|c|c|c|c|c|}
\hline \multirow{2}{*}{ Variables } & \multicolumn{2}{|c|}{ Model 1} & \multicolumn{2}{|c|}{ Model 2} & \multicolumn{2}{|c|}{ Model 3} \\
\hline & $\beta$ & $t$ & $\beta$ & $t$ & $\beta$ & $t$ \\
\hline Ideation & .38 & $6.18 * * *$ & .20 & $2.31 *$ & .01 & $.14 n . s$. \\
\hline Conventions & & & .25 & $2.87 * *$ & .09 & $1.11 \mathrm{n} . \mathrm{s}$. \\
\hline Self-regulation & & & & & .51 & $7.04 * * *$ \\
\hline$R^{2}$ & .15 & & .18 & & .33 & \\
\hline$\Delta R^{2}$ & .15 & & .03 & & .15 & \\
\hline$F$ & $38.19 * * *$ & & $23.83 * * *$ & & $35.87 * * *$ & \\
\hline$\Delta F$ & 38.19 & & 8.24 & & 49.59 & \\
\hline
\end{tabular}

ETWCF learner engagement with teacher written corrective feedback, n.s. non-significant

$* p<.05 . * * p<.01 . * * * p<.001$

for Model 1 was .15, indicating that self-efficacy for writing ideation alone explained $15 \%$ of the variance in the ETWCF $(F=38.19, p<.001)$. The standardized multiple regression coefficient (beta weight) of ideation was statistically significant $(\beta=.38 ; p<.001)$. In Model 2 with self-efficacy for conventions included, $R^{2}$ rose to .18 , meaning that the two control variables accounted for $18 \%$ of the variance in the ETWCF $(F=23.83, p<.001)$. In Model 2, the beta values of both self-efficacy for writing ideation $(p<.05)$ and self-efficacy for writing conventions $(p<.01)$ were statistically significant, whereas conventions accounted for a small additional amount of variance $\left(\Delta R^{2}=.03\right)$. The results of Model 2 suggested that selfefficacy for writing conventions $(\beta=.25)$ stimulated stronger learner engagement with teacher WCF than did self-efficacy for writing ideation, for which the beta value dropped from .38 to .20. In Model 3, the self-efficacy for writing self-regulation variable was added to Model 2. $R^{2}$ for the resulting model was .33 . With the addition of selfefficacy for writing self-regulation to step $3, R^{2}$ increased from .18 to .33 , an increase of $.15\left(\Delta R^{2}\right)$. In Model 3, the most noteworthy findings were that the variance accounted for by self-efficacy for writing ideation and self-efficacy for writing conventions dropped acutely when self-efficacy for writing self-regulation was added, with the beta weights of self-efficacy for writing ideation and self-efficacy for writing conventions becoming insignificant $(p>.05)$. Only the beta for self-efficacy for writing self-regulation was significant $(\beta=.51 ; p<.001)$. The results of Model 3 suggest that when all three variables are taken into account, self-efficacy for writing self-regulation is the only factor that can increase learner engagement with teacher WCF; the roles of self-efficacy for writing ideation and selfefficacy for writing conventions dwindled.
Table 6 shows how L2 writing self-efficacy influenced learner engagement with peer WCF. $R^{2}$ for Model 1 is .18 , signifying that self-efficacy for ideation alone explains $18 \%$ of the variance in the EPWCF $(F=47.66, p<.001)$. The standardized multiple regression coefficient (beta weight) of self-efficacy for writing ideation is statistically significant $(\beta=.42 ; p<.001)$. In Model 2 , which included self-efficacy for writing conventions, $R^{2}$ rose to .21 , meaning that the two control variables accounted for $21 \%$ of the variance in the EPWCF $(F=29.49, p<.001)$. In Model 2, the beta values of both self-efficacy for writing ideation $(p<.05)$ and self-efficacy for writing conventions $(p<.01)$ were statistically significant, whereas self-efficacy for writing conventions accounted for a small additional amount of variance $\left(\Delta R^{2}=.03\right)$. The results of Model 2 suggested that self-efficacy for writing conventions $(\beta=.26)$ stimulated stronger learner engagement with peer WCF than did self-efficacy for writing ideation whose beta value dropped from .42 to .23. In Model 3, the self-efficacy for writing self-regulation variable was added to Model 2. $R^{2}$ for the resulting model was .32 . With the addition of self-efficacy for writing self-regulation to Step $3, R^{2}$ increased from .21 to .32 , an increase of $.11\left(\Delta R^{2}\right)$. It is worth noting that in Model 3 , the variance accounted for by self-efficacy for writing ideation and for writing conventions decreased sharply when self-efficacy for writing self-regulation was added, with the beta weights of selfefficacy for writing ideation and for writing conventions becoming insignificant $(p>.05)$. Only the beta for selfefficacy for writing self-regulation was significant $(\beta=.43 ; p<.001)$. The results of Model 3 suggest that when all three variables were factored in, self-efficacy for writing self-regulation was the only component of L2 writing self-efficacy that could enhance learner engagement with peer WCF; the roles of self-efficacy for writing ideation and for writing conventions diminished.

\section{Discussion}

The participants in the present research self-reported a lowto-moderate level of L2 writing self-efficacy as a whole and on its individual subscales (including ideation, conventions, and self-regulation), which could be another reason for the participants' relatively low level of confidence in their English writing competence (Teng et al., 2018). The findings further indicate, as illustrated in Table 3, that the participants were more confident in their knowledge of writing conventions than in their writing ideation. Moreover, the results from Model 2 (Tables 5 or 6) show that the effect of self-efficacy for writing ideation on learner engagement with feedback was weaker than the effect of self-efficacy for writing conventions. It is, 
Table 6 Results of the hierarchical multiple regression: predicting EPWCF from L2 writing self-efficacy

\begin{tabular}{|c|c|c|c|c|c|c|}
\hline \multirow[t]{2}{*}{ Variables } & \multicolumn{2}{|c|}{ Model 1} & \multicolumn{2}{|c|}{ Model 2} & \multicolumn{2}{|c|}{ Model 3} \\
\hline & $\beta$ & $t$ & $\beta$ & $t$ & $\beta$ & $t$ \\
\hline Ideation & .42 & $6.90 * * *$ & .23 & $2.68 * *$ & .07 & .82 n.s. \\
\hline Conventions & & & .26 & $3.08 * *$ & .13 & 1.56n.s. \\
\hline Self-regulation & & & & & .43 & $5.90 * * *$ \\
\hline$R^{2}$ & .18 & & .21 & & .32 & \\
\hline$\Delta R^{2}$ & .18 & & .03 & & .11 & \\
\hline$F$ & $47.66^{* * *}$ & & $29.49 * * *$ & & $34.21 * * *$ & \\
\hline$\Delta F$ & 47.66 & & 9.51 & & 34.76 & \\
\hline
\end{tabular}

$E P W C F$ learner engagement with peer written corrective feedback, n.s. non-significant

$* * p<.01 . * * * p<.001$

therefore, more crucial to help learners first achieve a higher level of self-efficacy for writing conventions before helping them achieve a higher level of self-efficacy for writing ideation. However, as McCarthy (Savage \& Yeh, 2019) has argued, being understood is more important than forming grammatically perfect sentences. Also, generating and organizing ideas is generally considered the vital first step of the writing process. Therefore, teachers should design and use effective pre-writing strategies (e.g., graphic organizers, clustering, and freewriting) to help learners generate, clarify, and express their ideas in a methodical, coherent, and well-structured way, and thus help them develop both skills and self-efficacy in this regard. Further, as the participants were not confident that they were using the right words and phrases, teachers should use different effective strategies to help learners improve and expand their vocabulary (e.g., extensive reading and asking learners to keep a daily or weekly journal using words they have just learned) and to help them explore the nuanced meanings of words (e.g., illustrating common word-choice mistakes and encouraging learners to use thesauruses and dictionaries). With respect to taking steps to increase learners' self-efficacy related to composing complete, grammatically correct sentences, in addition to elucidating common grammar mistakes (e.g., subject-verb agreement and comma splices), teachers can employ focused feedback to assist learners in addressing certain types of grammar errors at a time, by focusing, for example, on the past tense or prepositions. Once learners have made significant progress in regard to addressing selfefficacy pertaining to ideation and conventions, learner engagement with teacher and peer feedback can likewise be expected to increase significantly, as evidenced separately in Models 1 and 2.
The participants also reported their low-to-moderate self-efficacy for writing self-regulation. Given that when all three L2 writing self-efficacy variables were taken into account (i.e., self-efficacy for writing ideation, conventions, and self-regulation), self-efficacy for writing selfregulation was the only one that could enhance learner engagement, whether in relation to teacher WCF or peer WCF (Model 3). The aforementioned findings correspond to Bruning et al.'s (2013) argument that, to a large degree, writing self-regulatory skills are required not only to help students generate productive ideas and utilize languagerelated tools to articulate those ideas into a written form, but also to manage, monitor, and evaluate their writing activities. In other words, based on the three models, it is a matter of the degree of importance regarding the three types of L2 writing self-efficacy at different levels. At the micro level, self-efficacy for writing ideation and for writing conventions plays an essential role in motivating students to engage with teacher and peer WCF. However, at the macro level, without self-efficacy for writing selfregulatory skills, students might not be able to brainstorm new ideas, use appropriate words/correct grammar or compose a coherent and well-structured essay/paragraph because of their inability to manage their anxieties and solve their difficulties. Accordingly, they might not have enough confidence to respond to the teacher and peer WCF. Therefore, it is relatively urgent for teachers, especially during the COVID-19 pandemic when learners need to learn to be independent and responsible (Deslandes-Martineau, 2020), to help learners develop and strengthen their self-efficacy in self-regulating the arduous and challenging learning process. For example, to keep students motivated and moving forward, and especially to help them stay socially connected while physically isolated (Ellis et al., 2020), teachers need to help them to connect with each other by creating virtual study groups (Gimenes, 2020) and to facilitate their learning by supporting each group's goals and offering regular feedback. However, as mentioned earlier, helping students develop self-efficacy for writing ideation and for writing conventions cannot be ignored.

\section{Conclusion}

The purpose of the current study was to explore the effects of EFL learners' L2 writing self-efficacy on their engagement with teacher and peer WCF. Via a quantitative approach, data provided by students at three senior high schools in northern Taiwan were analyzed. The findings suggest that the participants self-reported a low-to-moderate degree of L2 writing self-efficacy as a whole and in its three subscales (i.e., self-efficacy for writing ideation, selfefficacy for writing conventions, and self-efficacy for 
writing self-regulation). However, each subscale was shown to positively affect the extent to which participants responded to feedback as illustrated in the three models. Thus, to improve learners' writing skills, we argue that it is necessary for learners to develop L2 writing self-efficacy, especially self-efficacy for writing self-regulation. This is the case because, according to Bruning et al. (2013), selfregulatory skills are necessary for generating ideas and writing strategies, and for addressing problems such as anxiety. Moreover, based on the current study's findings, when the three subtypes are considered together, self-efficacy for writing self-regulation is the only factor remaining with predictive power for learning engagement with teacher and peer feedback, which may, in turn, lead to improved writing performance. Yet, some limitations in the present study should be acknowledged. Caution should be exercised against generalizing the results beyond the scope of the current study because the findings obtained here may not fully represent the entire population, that is, EFL learners in other learning contexts. Other research methods should also be considered in future investigations, such as interviewing participants and analyzing their writing assignments to further compare and understand how they respond to teacher and peer feedback (e.g., about local and global errors). In particular, a new questionnaire focusing on different dimensions of engagement (i.e., cognitive, social, behavioral, and affective) with WCF should be designed and validated, and their relationships with other variables such as classroom goal orientations should be scrutinized. Overall, in the current study, we propose critical and constructive implications for instructional practices in the L2 writing classroom to improve learners' self-efficacy and increase their engagement with WCF accordingly.

Acknowledgements I would like to express my sincere gratitude to Dr. Chaochang Wang for her constructive guidance and insightful suggestions.

\section{References}

Alemany-Arrebola, I., Rojas-Ruiz, G., Granda-Vera, J., \& Mingorance-Estrada, A. C. (2020). Influence of COVID-19 on the perceptions of academic self-efficacy, state anxiety, and trait anxiety in college students. Frontiers in Psychology, 11, 1-7. https://doi.org/10.3389/fpsyg.2020.570017

Bandura, A. (1995). Self-efficacy in changing societies. Cambridge University Press.

Berdanier, C. G. P., \& Lenart, J. B. (2020). So, You have to write a literature review: A guided workbook for engineers. The Institute of Electrical and Electronics Engineers Inc.

Bruning, R., Dempsey, M., Kauffman, D. F., McKim, C., \& Zumbrunn, S. (2013). Examining dimensions of self-efficacy for writing. Journal of Educational Psychology, 105(1), 25-38. https://doi.org/10.1037/a0029692

Cai, R., Wang, Q. Z., Xu, J. J., \& Zhou, L. J. (2020). Effectiveness of students' self-regulated learning during the COVID-19 pandemic. Science Insights, 34(1), 175-182. https://doi.org/10.15354/si.20.ar011

Caraway, K., Tucker, C. M., Reinke, W. M., \& Hall, C. (2003). Selfefficacy, goal orientation and fear of failure as predictors of school engagement in high school students. Psychology in the Schools, 40(4), 417-427. https://doi.org/10.1002/pits.10092

Chomeya, R. (2010). Quality of psychology test between Likert Scale 5 and 6 Points. Journal of Social Sciences, 6(3), 399-403.

Daniels, S., McCurdy, M., Whitsitt, L., Skinner, C. J., SchwartzMicheaux, J., \& White, J. (2019). Evaluating the effects of a writing self-efficacy intervention on writing quantity in middle school students. Reading \& Writing Quarterly, 36(1), 48-64. https://doi.org/10.1080/10573569.2019.1618226

Demetriou, C., Ozer, B. U., \& Essau, C. (2015). Self-report questionnaires. In R. Cautin \& S. Lilienfeld (Eds.), The encyclopedia of clinical psychology. Wiley.

Deslandes-Martineau, M. (2020). Education and COVID-19: Challenges and opportunities. https://en.ccunesco.ca/idealab/education-and-covid-19challenges-and-opportunities

Ellis, R. (2010). A framework for investigating oral and written corrective feedback. Studies in Second Language Acquisition, 32(2), 335-349. https://doi.org/10.1017/S0272263109990544

Ellis, W. E., Dumas, T. M., \& Forbes, L. M. (2020). Physically isolated but socially connected: Psychological adjustment and stress among adolescents during the initial COVID-19 crisis. Canadian Journal of Behavioural Science/Revue Canadienne Des Sciences Du Comportement, 52(3), 177-187. https://doi.org/10.1037/cbs0000215

George, D., \& Mallery, P. (2001). SPSS for Windows: A simple guide and reference. Pearson Education.

Gimenes, L. (2020, November 9). Students form Zoom study groups to navigate online classes, connect with Peers. The Brown Daily Herald.

https://www.browndailyherald.com/2020/11/09/students-formzoom-study-groups-navigate-online-classes-connect-peers/

Hedgcock, J., \& Lefkowitz, N. (1994). Feedback on feedback: Assessing learning receptivity to teacher response in L2 composing. Journal of Second Language Writing, 3, 141-163. https://doi.org/10.1016/1060-3743(94)90012-4

Horbacauskiene, J., \& Kasperaviciene, R. (2015). Learners' preferences towards Corrective feedback in writing assignments in tertiary education. Explorations in English Language and Linguistics, $\quad 3(2), \quad 70-83$. https://doi.org/10.1515/exell-2017-0002

Kaoa, C. W., \& Reynoldsb, B. L. (2017). A study on the relationship among Taiwanese College students' EFL writing strategy use, writing ability and writing difficulty. English Teaching \& Learning, $\quad 41(4), \quad 31-67$. https://doi.org/10.6330/ETL.2017.41.4.02

Kavanoz, S., \& Yüksel, H. G. (2016). Developing and validating a self-efficacy scale for scholarly writing in English. International Online Journal of Educational Sciences, 8(2), 71-82. https://doi.org/10.15345/iojes.2016.02.007

Kim, Y. H., Kim, D. J., \& Wachter, K. (2013). A study of Mobile User Engagement (MoEN): Engagement motivations, perceived value, satisfaction, and continued engagement intention. Decision Support Systems, 56, 361-370. https://doi.org/10.1016/j.dss.2013.07.002

Kirmizi, Ö., \& Kirmizi, G. D. (2015). An investigation of L2 learners' writing self-efficacy, writing anxiety and its causes at higher 
education in Turkey. International Journal of Higher Education, 4(2), 57-66. https://doi.org/10.5430/ijhe.v4n2p57

Kline, R. B. (1998). Principles and practice of structural equation modeling. Guilford.

Lindsey, H. L. (2017). Self-efficacy, student engagement, and student learning in introductory statistics. [Unpublished doctoral dissertation]. Montana State University. https://scholarworks.montana.edu/xmlui/bitstream/handle/1/ 12794/LindseyH0517.pdf?sequence $=4$

Linnenbrink, E. A., \& Pintrich, P. R. (2003). The role of self-efficacy beliefs in student engagement and learning in the classroom. Reading \& Writing Quarterly: Overcoming Learning Difficulties, 19(2), 119-137. https://doi.org/10.1080/10573560308223

Lynch, R., Hurley, A., Cumiskey, O., Nolan, B., \& McGlynn, B. (2019). Exploring the relationship between homework task difficulty, student engagement and performance. Irish Educational Studies, $\quad 38(1), \quad$ 89-103. https://doi.org/10.1080/03323315.2018.1512889

Myhill, D., \& Jones, S. (2007). More than just error correction: Students' perspectives on their revision processes during writing. Written Communication, 24(4), 323-343. https://doi.org/10.1177/0741088307305976

Pajares, F., \& Valiante, G. (1999). Grade level and gender differences in the writing self-beliefs of middle school students. Contemporary Educational Psychology, 24(4), 390-405. https://doi.org/10.1006/ceps.1998.0995

Papa, L. A. (2015).The impact of teaching and academic self-efficacy on student engagement and academic outcomes. [Unpublished doctoral dissertation]. Montana State University. https://digitalcommons.usu.edu/cgi/ viewcontent.cgi?article $=5397 \&$ context $=$ etd

Price, M., Handley, K., \& Millar, J. (2011). Feedback: Focusing on engagement. Studies in Higher Education, 36(8), 879-896. https://doi.org/10.1080/03075079.2010.483513

Putarek, V., \& Pavlin-Bernardić, N. (2020). The role of self-efficacy for self-regulated learning, achievement goals, and engagement in academic cheating. European Journal of Psychology of Education, 35, 647-671. https://doi.org/10.1007/s10212-019-00443-7

Qi, D. S., \& Lapkin, S. (2001). Exploring the role of noticing in a three-stage second language writing task. Journal of Second Language Writing, $10(4), \quad 277-303$. https://doi.org/10.1016/S1060-3743(01)00046-7

Quweneel, E., Schaufeli, W. B., \& Blanc, P. M. L. (2013). Believe, and you will achieve: Changes over time in self-efficacy, engagement, and performance. Applied Psychology: Health and Wellbeing, 5(2), 225-247. https://doi.org/10.1111/aphw.12008

Savage, V., \& Yeh, P. (2019). Novelist Cormac McCarthy's tips on how to write a great science paper. Nature, 574, 441-442. https://doi.org/10.1038/d41586-019-02918-5

Schunk, D. H., \& Mullen, C. A. (2012). Self-efficacy as an engaged learner. In S. L. Christeenson, A. L. Reschly, \& C. R. F. Wylie (Eds.), Handbook of research on student engagement (pp. 219-235). H. Dordrecht Springer Science+Business Media.

Sharma, H. L., \& Nasa, G. (2014). Academic self efficacy: A reliable predictor of educational performances. British Journal of Education, 2, 57-64.

Shaughnessy, M. P. (1977). Errors and expectations: A Guide for the teacher of basic writing. Oxford University Press.
Simin, S., \& Tavangar, M. (2009). Metadiscourse knowledge and use in Iranian EFL writing. The Asian EFL Journal Quarterly, 1(1), 230-255.

Svalberg, A. (2012). Language awareness in language learning and teaching: A research agenda. Language Teaching, 45(3), 376-388. https://doi.org/10.1017/S0261444812000079

Teng, L. S., Sun, P. P., \& Xu, L. (2018). Conceptualizing writing selfefficacy in English as a foreign language context: Scale validation through structural equation modeling. TESOL Quarterly, 52(4), 911-942. https://doi.org/10.1002/tesq.432

Tsao, J. J., Tseng, W. T., \& Wang, C. C. (2017). The effects of writing anxiety and motivation on EFL college students' selfevaluative judgments of corrective feedback. Psychological Reports, $120(2)$,

219-241. https://doi.org/10.1177/0033294116687123

Usher, E. L., \& Pajares, F. (2008). Self-efficacy for self-regulated learning a validation study. Educational and Psychological Measurement, 68(3), 443-463. https://doi.org/10.1177/0013164407308475.

Walker, C. O., Greene, B. A., \& Mansell, R. A. (2006). Identification with academics, intrinsic/extrinsic motivation, and self-efficacy as predictors of cognitive engagement. Learning and Individual Differences, 16(1), 1-12. https://doi.org/10.1016/j.lindif.2005.06.004

Woodrow, L. (2011). College English writing affect: Self-efficacy and anxiety. System, 9(4), 510-522. https://doi.org/10.1016/j.system.2011.10.017

Wright, A. J., \& Pade, H. (2020). Supervising psychological assessment report writing. In A. J. Wright (Ed.), Essentials of psychological assessment supervision (pp. 243-262). Wiley.

Yu, S. L., Jiang, L. J., \& Zhou, N. (2020). Investigating what feedback practices contribute to students' writing motivation and engagement in Chinese EFL context: A large scale study. Assessing Writing, 44, 1-15. https://doi.org/10.1016/j.sde.2020.100451

Zhang, H. W. (2017). A study of written corrective feedback and its effect on Chinese Junior Learners' English Writing. Sino-US English Teaching, 14(7), 403-413. https://doi.org/10.17265/1539-8072/2017.07.001

Zhang, Y. (2018). Exploring EFL learners' self-efficacy in academic writing based on process-genre approach. English Language Teaching, 11(6), 115-124. https://doi.org/10.5539/elt.v11n6p115

Zhang, Z., \& Hyland, K. (2018). Student engagement with teacher and automated feedback on L2 writing. Assessing Writing, 36, 90-102. https://doi.org/10.1016/j.asw.2018.02.004

Zimmerman, B. J., \& Bandura, A. (1994). Impact of self-regulatory influences on writing course attainment. American Educational $\begin{array}{lll}\text { Research } \quad \text { Journal, } & \text { 845-862. }\end{array}$ https://doi.org/10.3102/00028312031004845

Zumbrunn, S., Broda, M., Varier, D., \& Conklin, S. (2019). Examining the multidimensional role of self-efficacy for writing on student writing self-regulation and grades in elementary and high school. British Journal of Educational Psychology, 90(3), 580-603. https://doi.org/10.1111/bjep.12315

Publisher's Note Springer Nature remains neutral with regard to jurisdictional claims in published maps and institutional affiliations. 